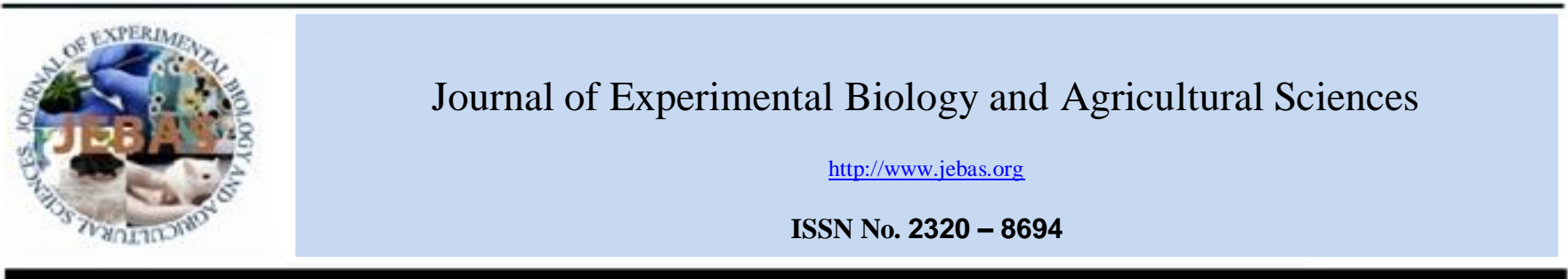

\title{
RATIONAL SYNCHRONOUS ELECTRIC DRIVE OF AGRICULTURAL PUMPS
}

\section{Igor Grigorievich Strizhkov", Sergey Vladimirovich Oskin, Georgii Akhmedovich Sultanov, Vladimir Stanislavovich Kurasov, Vadim Nikolaevich Pleshakov}

Kuban State Agrarian University, ul. Kalinina 13, Krasnodar, Russia

Received - August 29, 2017; Revision - September 21, 2017; Accepted - October 29, 2017

Available Online - October 31, 2017

http://dx.doi.org/10.18006/2017.5(5).684.689

KEYWORDS
Energy saving
Agricultural pumps
Water main
Synchronousmotor
Transformer

\begin{abstract}
This article discusses design and mathematical description of rational synchronous electric drive of portable irrigation pumps. This electric drive makes it possible to decrease wasteful energy loss for irrigation due to improvement of energy performances of electric drive. Electric drives of irrigation pumps are the most energy intensive power consumers in agricultural industry, which often operate from long distance power transmission line, improvement in their energy performances decreases power loss both on the drive itself and in supply line. Power supply line for irrigation purposes usually operates with the voltage of $10 \mathrm{kV}$, whereas the voltage of rational motors for pump drives is below $1000 \mathrm{~V}$. Under such conditions it would be reasonable to operate transformer-motor assemblies, which optimize control and protection of pump assemblies. Such assemblies enable rationalization of control device of synchronous motor in pump drive by simplifying exciter with retention of automatic excitation control in function of mechanical load and motor supply voltage. This article presents mathematical description of transient and steady electromagnetic processes in transformer-motor assemblies of the considered design.
\end{abstract}

* Corresponding author

E-mail: interkubsau@mail.ru (Igor Grigorievich Strizhkov)

Peer review under responsibility of Journal of Experimental Biology and Agricultural Sciences.

Production and Hosting by Horizon Publisher India [HPI] (http://www.horizonpublisherindia.in/).

All rights reserved.
All the article published by Journal of Experimental Biology and Agricultural Sciences is licensed under a Creative Commons Attribution-NonCommercial 4.0 International License Based on a work at www.jebas.org.

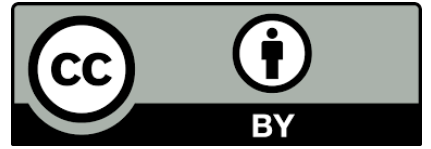




\section{Introduction}

Nearly all Russian agricultural regions are characterized by unsteady moistening stipulated by deficit in natural precipitations or existence of waterlogged soils. Under such conditions artificial irrigation and reclamation of lands are highly efficient approach to agriculture (Shchedrin, 2004). This is aided by portable pumps with diesel or electric drive. Such pumps are also used as reserve ones for emergency water supply of residential areas and industrial facilities, for their fire protection and other purposes.

According to data by US Hydraulic Institute and European National Pump Association, about 20\% of global electric power is consumed by pump stations (Shchedrin, 2004). If all expenses for procurement and operation of pump assemblies are set to $100 \%$, then the main expenses for procurement, maintenance, electric power, without costs of water in 10 years of operation will be distributed as $85 \%$ power costs; $10 \%$ maintenance and remaining $5 \%$ for the procurement of equipment (Shchedrin, 2004).

Since the most expensive portion is the power consumption by pump station, then one of the most efficient ways of their improvement is increase in their power performances: either in efficiency or in power factor (Oskin, 1996). In addition, the assemblies should be equipped with reliable, easily controllable electric drive characterized by required electromechanic properties, high power performances and possibly low cost. Insufficient reliability of drives is related with significant economic costs (Kopylov, 2000). Non-adjustable alternative current drives are widely applied in irrigation, including asynchronous and synchronous, each of them is characterized by known advantages (Syromyatneykov, 1963; Beglyarov \& Strizhkov, 2010). The first ones are used up to $100 \mathrm{~kW}$, and the latter above $500 \mathrm{~kW}$. At the range of $100-500 \mathrm{~kW}$ both drive types are used and it is exactly the range which is required for portable pump stations (Oskin \& Didych, 2011; Oskin, 2014). Present study aim to discuss the design and mathematical description of rational synchronous electric drive of portable irrigation pumps.

\section{Materials and Methods}

New design of synchronous motor for pumps is proposed by Kuban state agrarian university, Russia (Fig. 1) It differs from conventional synchronous motors by the connection circuit of stator (armature) winding, which in addition to common functions acts as compound chain of motor excitation system instead of expensive external exciters aiming at provision of preset sequence of automatic adjustment of excitation, thus resulting in simpler and less expensive motor (Strizhkov et al., 2006a; Strizhkov et al., 2006b; Strizhkov et al., 2009; Strizhkov et al., 2012a). Peculiar feature of armature winding makes it possible to solve efficiently the issue of reduction of starting current using starting of section motor (Strizhkov et al., 2010a). Using the proposed motor as pump drive of stationary facilities makes it possible to combine high power performances and relatively low cost of the drive. It is known that economic efficiency of serial synchronous motors is usually limited by $100 \mathrm{~kW}$, and in actual agricultural irrigation the lower limit of pumps with synchronous drive is $200 \mathrm{~kW}$.

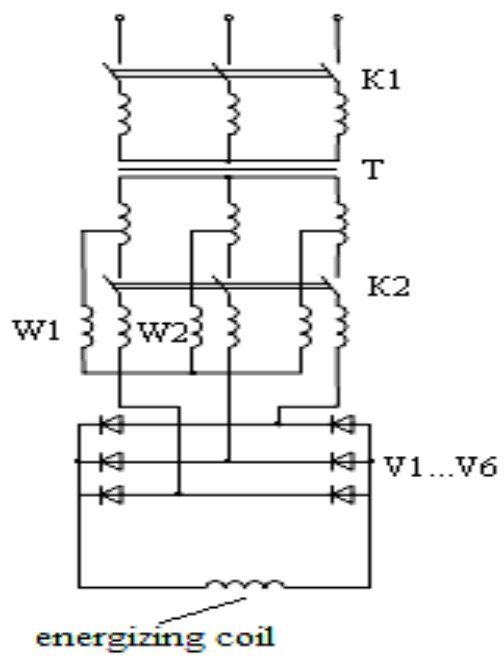

Figure 1 Pump electric drive flowchart

Engineering and economic analysis revealed that at present the use of synchronous motor with twin armature winding (SMTW) for agricultural purposes allows to decrease this limit to $60 \mathrm{~kW}$, and in some cases even to $50 \mathrm{~kW}$ (Beglyarov \& Strizhkov, 2010). This is achieved due to the various advantages of SMTW, among these some common are (i) decrease in drive dimensions and weight in comparison to serial motor, (ii) availability of automatic adjustment of excitation, (iii) decrease in starting current to 1.251.75-fold upon switching of armature winding sections for the period of asynchronous start and (iv) holding of high overload and compensating ability upon possible non-emergency voltage decrease in supply circuit.

Modern electric engineering proposes various approaches to study and simulation of machinery and valves. The most widely used is the method of mathematical description of electromagnetic processes by equilibrium equations of currents and voltages of electric circuits included in the considered object in combination with motion equation of electric drive. The theory of synchronous motors is based on generalized electromechanic transformation of coordinates upon its mathematical description (Kopylov, 2000). This theory is discussed in details with regard to synchronous motors with several magnetically coupled three-phase windings 
on stator (Strizhkov, 2012). This article presents results of mathematical description of electric equipment of transformerSMTW assembly in d, q coordinates rigidly coupled with rotor. The mentioned coordinates are common rational system for description of synchronous machines. This work uses relative units, common for transformer and motor, the basic principles of the units are described in Strizhkov (2013). Mathematical descriptions of the assembly are given in dynamic modes in the form of non-linear differential equations and in static modes in the form non-linear algebraic equations.

\section{Results}

General mathematical description of the assembly is comprised of equations of transformer and motor, given in unified system of relative units with basic voltage and current, equating to nominal values for motor. While solving problems of analysis electromagnetic processes in electric motor, it is reasonable to present transformer by equivalent circuit (Kopylov, 2000), which significantly simplifies the mathematical model and provides acceptable error of calculations. Herewith, transformer idle current is neglected; it amounts to about $3 \%$ of nominal value and does not significantly influence currents in motor windings, thus, it is reasonable to introduce assumption about proportionality of voltages on outputs of transformer secondary winding. The error resulting from neglecting processes in magnetizing branch is lower by an order of magnitude than the error added by assumptions idealizing motor and transformer. If required, the transformer idle current can be taken into account as the current of independent branch ported out to terminals of power source (circuit).

While solving the problems of analysis of processes in transformer windings as well as while developing universal mathematical model of transformer-SMTW assembly, it is required to use the equations of transformer voltage equilibrium. In this case the set of equations of mathematical description of the assembly is as follows (Strizhkov, 2012; Strizhkov, 2013; Strizhkov et al., 2010b):

$$
\begin{aligned}
& u_{d}=-U_{m} \sin \gamma ; \quad u_{q}=U_{m} \cos \gamma \\
& \frac{d \psi_{d 1}}{d t}=u_{d 1}-r_{1} i_{d 1}+\omega \psi_{q 1} ; \frac{d \psi_{d 1}}{d t}=u_{d 1}-r_{1} i_{d 1}-\omega \psi_{q 1} \\
& \frac{d \psi_{d 2}}{d t}=u_{d 2}-\left(r_{2}+r_{1}\right) i_{d 2}+x_{f} i_{q 2}+\omega \psi_{q 2}-\frac{i_{d 2} \cos \varphi_{f}-i_{q 2} \sin \varphi_{1} d \psi_{f}}{\beta_{r} i_{f}} \\
& \frac{d \psi_{q 2}}{d t}=u_{q 2}-\left(r_{2}+r_{1}\right) i_{q 2}-x_{f} i_{d 2}-\omega \psi_{d 2}-\frac{i_{d 2} \sin \varphi_{f}{ }^{-} i_{q 2} \cos \varphi_{1} d \psi_{f}}{\beta_{r} i_{f}}
\end{aligned}
$$

$$
\begin{aligned}
& \frac{d \psi_{y d}}{d t}=-r_{y d} i_{y d} ; \frac{d \psi_{y q}}{d t}=-r_{y q} i_{y q} ; \\
& \frac{d \omega}{d t}=\left(\psi_{d 1} i_{q 1}-\psi_{q 1}{ }^{i} d 1+\psi_{d 2^{i}} q 2-\psi q 2^{i} d 2-m_{c}\right) / J \\
& \frac{d \gamma}{d t}=\omega ; \beta_{r}=\beta_{u} / \beta_{i} ;
\end{aligned}
$$$$
u_{d}=r_{1 T} i_{d}+x_{T 1} \frac{d i_{d}}{d t}+x_{T 12} \frac{d i_{d 1}}{d t}+x_{T 13} \frac{d i_{d 2}}{d t} ;
$$$$
u_{d 1}=r_{2 T} i_{d 1}+x_{T 2} \frac{d i_{d 1}}{d t}+x_{T 21} \frac{d i_{d}}{d t}+x_{T 23} \frac{d i_{d 2}}{d t} ;
$$$$
u_{d 2}=r_{3 T^{i}}{ }_{d 2}+x_{T 2} \frac{d i_{d 2}}{d t}+x_{T 12} \frac{d i_{d}}{d t}+x_{T 23} \frac{d i_{d 1}}{d t} ;
$$$$
u_{q}=r_{1 T} i_{q}+x_{T 1} \frac{d i_{q}}{d t}+x_{T 12} \frac{d i_{q 1}}{d t}+x_{T 13} \frac{d i_{q 2}}{d t} ;
$$$$
u_{q 1}=r_{2 T^{i}}{ }_{q 1}+x_{T 12} \frac{d i_{q 1}}{d t}+x_{T 1} \frac{d i_{q}}{d t}+x_{T 23} \frac{d i_{q 2}}{d t}
$$$$
u_{q 2}=r_{3 T} i_{q 2}+x_{T 23} \frac{d i_{q 2}}{d t}+x_{T 3} \frac{d i_{q}}{d t}+x_{T 23} \frac{d i_{q 1}}{d t} .
$$$$
\psi_{d 1}=x_{d 1}{ }^{i} d 1+x_{d 2^{i} d 2}+x_{d f} i_{f}+x_{d y d} d_{y d} ;
$$$$
\psi_{d 2}=x_{d 2}{ }^{i} d 1+x_{d 1}{ }^{i} d 2+x_{d f} f_{f}+x_{d y d} d_{y d}
$$$$
\psi_{f}=x_{d 1}\left(i_{d 1}+i_{d 2}\right)+x_{f} i_{f}+x_{f y d} i_{y d}
$$$$
\psi_{y d}=x_{d 1 d y}\left(i_{d 1}+i_{d 2}\right)+x_{f y d} i_{f}+x_{y d} i_{y d}
$$$$
\psi_{q 1}=x_{q 1} i_{q 1}+x_{q 2} i_{q 2}+x_{q y q} i_{y q}
$$$$
\psi_{q 2}=x_{q 2}{ }^{i} q 1+x_{q 1} i_{q 2}+x_{q y q} i_{y q}
$$

$\psi_{y q}=x_{q y q}\left(i_{q 1}+i_{q 2}\right)+x_{y q} i_{y q}$,

where $U_{m}$ is the voltage amplitude of supply circuit; $u_{d}, u_{d 1}, u_{d 2}, u_{q}$, $u_{q 1}, u_{q 2}$ are the voltages on transformer primary winding, winding $\mathrm{W} 1$ and winding $\mathrm{W} 2$, respectively, along longitudinal axis $(d)$ and 
transversal axis $(q)$ of orthogonal coordinates $d, q ; i_{d}, i_{d 1}, i_{d 2}, i_{q}, i_{q 1}$, $i_{q 2}$ are the currents on transformer primary winding, winding W1 and winding $\mathrm{W} 2$, respectively, along longitudinal and transversal axes; $r_{1 \mathrm{~T}}, r_{2 \mathrm{~T}}, r_{3 \mathrm{~T}}$ are the active resistances of primary and secondary transformer windings; $x_{T 1}, x_{T 2}, x_{T 3}, x_{T 12}, x_{T 13}, x_{T 23}$ are the induction resistances of self-induction and mutual induction of primary and secondary transformer windings, respectively; $r_{1}, r_{2}$, $r_{f}$ are the active resistances of windings $\mathrm{W} 1, \mathrm{~W} 2$ and excitation winding, respectively; $x_{d 1}, x_{d 2}, x_{d f}, x_{d y d}, x_{q 1}, x_{q 2}, x_{q y q}$ are the induction resistances of self-induction and mutual induction of synchronous motor; $\omega$ is the angular rotor frequency; $\gamma$ is the load angle; $\beta_{\mathrm{u}}, \beta_{\mathrm{i}}, \beta_{\mathrm{r}}$ are the coefficients of bridge rectifier with regard to voltage, current, and resistance, respectively (Strizhkov et al., $2012 \mathrm{~b}) ; \psi_{d 2}, \psi_{d 1}, \psi_{q 1}, \psi_{q 2}, \psi_{f}, \psi_{y d}, \psi_{y q}$ are the linkage of windings $\mathrm{W} 1, \mathrm{~W} 2$, excitation winding and damper winding, respectively, along coordinate axes $d, q$.

One of properties of asynchronous motor determining its operation performances is the law of automatic excitation adjustment. The most reasonable for irrigation pump drive at free standing pump stations is the law of excitation adjustment with regard to constant zero reactive power.

Parameters of transformer and motor providing for preset excitation law are determined on the basis of equations of static operation mode of the drive.

Secondary transformer voltages $U_{1}$ and $U_{2}$ in static modes without great error can be considered as independent from motor load mode (with regard to current in windings). No electromagnetic processes occur in electric circuits of damper (starting) winding, since electromotive force (EMF) in these windings along $d$ and $q$ axes is not induced and damper currents are zero. Taking into account these assumptions the equations of static mode are as follows:

$$
\begin{aligned}
& U_{d 1}=r_{2} I_{d 1}-\psi_{q 1}=-U_{1} \sin \Theta ; \\
& U_{d 2}=r_{3} I_{d 2}-\psi_{q 1}=-U_{2} \sin \Theta \\
& U_{d 1}=R_{2} I_{q 1}+\psi_{d 1}=U_{1} \cos \Theta ; \\
& U_{d 2}=R_{2} I_{q 2}+\psi_{d 2}=U_{2} \cos \Theta ; \\
& \psi_{d 1}=x_{d 1} I_{d 1}+x_{d 3^{I}} d 2+x_{d 1 f^{I} f} ; \\
& \psi_{d 2}=x_{d 3} I_{d 1}+x_{d 2} I_{d 2}+x_{d 1 f} I_{f} ; \\
& \psi_{q 1}=x_{q 1} I_{q 1}+x_{q 3} I_{q 1} ; \psi_{q 2}=x_{q 3} I_{q 1}+x_{q 2} I_{q 2} ; \\
& I_{f}=\beta_{1} \sqrt{I_{d 2}^{2}+I_{q 2}^{2}} ; U_{2}=k_{1} U_{1} ; \\
& M=\psi_{d 1^{I}}{ }_{q 1}+\psi_{d 2^{I}}{ }_{q 1}-\psi_{q 1}{ }^{I} d 1-\psi_{q 2}{ }^{I} d 2
\end{aligned}
$$

In the equations the motor variables are denoted as: $R_{2}=r_{2}+r_{\mathrm{f}}$ is the cumulative active resistance of through stator winding, bridge rectifier, and excitation winding (that is, electric circuit of through winding); $x_{d 2}=x_{d 1}+x_{\mathrm{f}}$ is the cumulative induction resistance of through stator winding, bridge rectifier, and excitation winding in the coordinate $d ; x_{q 2}=x_{q 1}+x_{\mathrm{f}}$ is the cumulative induction resistance of through stator winding, bridge rectifier, and excitation winding in the coordinate $q$; $k_{t}$ is the ratio of secondary transformer voltages upon idle run; the variables are denoted by capital letters, the same as in equation 1.

Rectifier-excitation winding assembly in the equations of static mode is presented by passive assembly with active induction resistance (parameters $r_{\mathrm{f}}$ and $\mathrm{x}_{\mathrm{f}}$ ).

\section{Discussion}

The set of equations 2 contains non-linear equations of momentum and excitation current, this set is non-linear and has no standard solutions. It can be solved by particular solution algorithm and by methods of mathematical simulation. At present applied simulation proposes various forms and simulating software for electromechanic systems. The transformer-SMTW assembly could be most reasonably studied using MatlabSimulink (Strizhkov \& Beglyarov, 2009; Strizhkov et al., 2012a; Strizhkov et al., 2013; Oskin, 2014; Strizhkov et al., 2014; Strizhkov \& Chesnyuk 2015).

The variables $P, Q=f(\theta)$ in the theory of synchronous machines are considered as angular properties. Comparison of experimental data with simulated data (Figure 2 ) in the range of 0 $<\theta<0.5$ revealed deviation in active power not higher than $5 \%$ and in reactive power not higher than $7 \%$ of experimentally measurements.

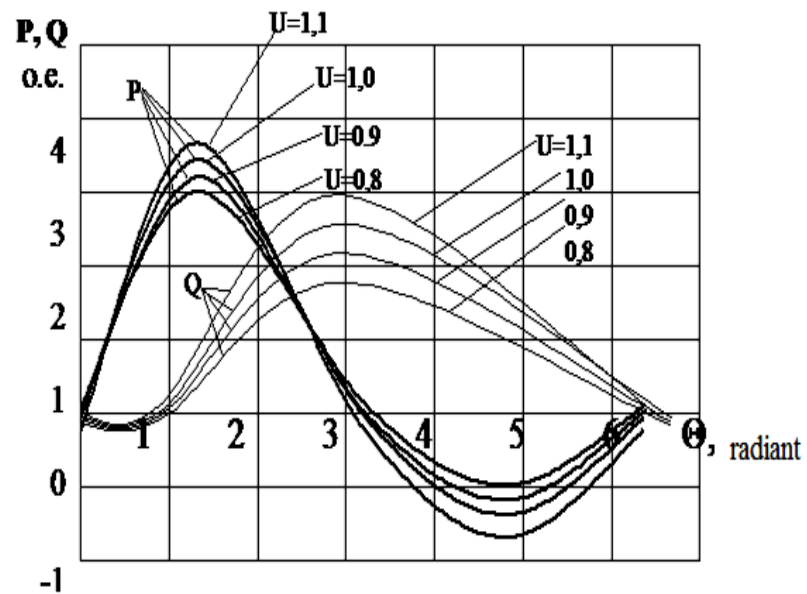

Figure 2 Angular properties of motor at various voltages 


\section{Conclusion}

This article presented mathematical description of rational electric drive of portable irrigation pumps on the basis of transformersynchronous motor assembly, which allows to determine the required practical properties of the considered drive using mathematical methods or to construct mathematical model of electric drive in static and dynamic operation modes.

For pump drive of portable pump assemblies intended for artificial irrigation or reclamation of agricultural or other lands in the districts with well-developed power supply overhead lines with the voltage above $1000 \mathrm{~V}$ it would be reasonable to use the proposed electric drive with transformer-synchronous motor assembly developed by Kuban state agrarian university. The design of the electric drive allows to use the set of electric control and protection equipment with the voltage below $1000 \mathrm{~V}$ and provides minimization of current in supply line as a function of operation of pump assembly and minimization of power loss in supply line and own equipment of pump assembly.

\section{References}

Beglyarov RR, Strizhkov SI (2010) Sravnitel naya ekonomicheskaya effektivnost' sinkhronnogo i asinkhronnogo privodov mobilnykh meliorativnykh nasosov [Comparison of economic efficiency of synchronous and asynchronous drives of portable agricultural drives]. Scientific magazine, University: science, concepts and solutions 2: 176-179.

Kopylov IP (2000) Elektricheskie mashiny [Electric machines]. Textbook. Vysh. Shkola, Logos, Moscow.

Oskin SV (1996) Povyshenie nadezhnosti elektroprivoda sel'skohozyaistvennykh mashin [Reliability improvement of electric drive of agricultural machinery]. Mekhanizatsiya i Elektrifikatsiya Sel'skogo Khozyaistva 3: 19

Oskin SV (2014) Avtomatizirovannyi elektroprivod [Automated electric drive]. Textbook, KRON, Krasnodar.

Oskin SV, Didych VA (2011) Energosberezhenie v nasosnykh ustanovkakh sistem melioratsii $\mathrm{i}$ orosheniya [Power saving in pump assemblies of reclamation systems]. Izvestiya Akademii Elektrotekhnicheskikh Nauk RF 2: 55.

Shchedrin VN (2004) Oroshenie segodnya; problemi i perspectivi [Irrigation today: problems and perspectives] Federal State Scientific Organization "Scientifical and technical information centre 'Meliovodinform”, Moscow.

Strizhkov IG (2012) Osnovy teorii sinkhronnykh mashin s neskol 'kimi obmotkami na statore [Theoretical foundations of synchronous machines with several stator windings]. KubGAU, Scientific magazine 84(10): 1-39. Retrieved from: http://ej.kubagro.ru/2012/10/pdf/36.pdf

Strizhkov IG (2013) Sistemy otnositel nykh edinits v teorii sinkhronnykh mashin $\mathrm{s}$ neskol'kimi obmotkami na statore [Relative units in theory of synchronous machines with several stator windings]. KubGAU, Scientific magazine 91(07). Retrieved from: http://ej.kubagro.ru/2013/07/pdf/97.pdf

Strizhkov IG, Beglyarov RR (2009) Elektroprivod orositel nogo nasosa na baze sinkhronnogo dvigatelya $\mathrm{s}$ dvoinoi yakornoi obmotkoi [Electric drive of irrigation pump on the basis of synchronous motor with twine armature winding].Kuban state agrarian university. Scientific magazine 1: 197-199.

Strizhkov IG, Beglyarov RR, Strizhkov SI, Trubin AN (2009) RF Patent $2354035 \mathrm{C} 1$. Transformer-synchronous motor assembly.

Strizhkov IG, Beglyarov RR, Strizhkov SI, Trubin AN (2010a) RF Patent 2396692 C1. Starter of synchroonus motor.

Strizhkov IG, Beglyarov RR, Zagnitko VN, Strizhkov SI, Trubin AN (2012a) RF Patent 2457609 C1. Transformer-contactless synchronous motor.

Strizhkov IG, Chesnyuk EN (2015) Dvukhskorostnoi sinkhronnoasinkhronnyi dvigatel [Two-speed synchronous-asynchronous motor]. Mekhanizatsiya i Elektrifikatsiya Sel'skogo Khozyaistva 10:7-10.

Strizhkov IG, Chesnyuk EN, Beglyarov RR (2014) Elektrooborudovaniemobil nykh nasosnykh ustanovok [Electric equipment of portable pump assemblies]. Proceedings, Workshop. Krasnodar: KubGAU, Pp. 591-592.

Strizhkov IG, Chesnyuk EN, Beglyarov RR, Strizhkov SI (2012b) Modelirovanie vypryamitelya $\mathrm{V}$ sistemakh vozbuzhdeniya spetsial nykh sinkhronnykh dvigatelei [Simulation of rectifier in excitation systems of special synchronous motors]. KubGAU. Scientific magazine 5: 155-159.

Strizhkov IG, Chesnyuk EN, Beglyarov RR, Strizhkov SI (2013) Rectifier modelling in excitation systems of special synchronous motors. Kybernetika. Verlag, Hannover. 10:35-43

Strizhkov IG, Trubin AN, Beglyarov RR (2010b) Matematicheskaya model sinkhronnogo privoda peredvizhnykh orositel nykh nasosnykh ustanovok [Mathematical model of synchronous drive of mobile irrigation pump systems]. Kuban state agrarian university. Scientific magazine 1: 161-164.

Strizhkov IG, Trubin AN, Strizhkov SI (2006a) RF Patent 2271599 C1. Synchronous electric machine. 
Strizhkov IG, Trubin AN, Strizhkov SI (2006b) RF Patent 2272351 RU C1. Synchronous motor.

Syromyatneykov IA (1963) Rezhimy raboty asinkhronnykh i sinkhronnykh elektrodvigatelei [Operation modes of synchronous and asynchronous electric motors]. 